\title{
PENGEMBANGAN E-MODUL BERBASIS MODEL PEMBELAJARAN DISCOVERY LEARNING PADA MATA PELAJARAN "SISTEM KOMPUTER" UNTUK SISWA KELAS X MULTIMEDIA SMK NEGERI 3 SINGARAJA
}

\author{
Komang Wisnu Baskara Putra1), I Made Agus Wirawan'2), Gede Aditra Pradnyana ${ }^{3)}$ \\ ${ }^{1}$ Fakultas Teknik dan Kejuruan, Universitas Pendidikan Ganesha (penulis 1) \\ email:1215051073@undiksha.ac.id \\ ${ }^{2}$ Fakultas Teknik dan Kejuruan, Universitas Pendidikan Ganesha (penulis 2) \\ email : imade.aguswirawan@undiksha.ac.id \\ ${ }^{3}$ Fakultas Teknik dan Kejuruan, Universitas Pendidikan Ganesha (penulis 3) \\ email : gede.aditra@undiksha.ac.id
}

\begin{abstract}
Abstrak
Penelitian ini bertujuan untuk (1) Untuk menghasilkan rancangan dan mengimplementasikan hasil rancangan e-modul berbasis model pembelajaran discovery learning pada mata pelajaran sistem komputer kelas $X$ multimedia di SMK Negeri 3 Singaraja, (2) Untuk mengetahui respon guru dan siswa terhadap pengembangan emodul berbasis model pembelajaran discovery learning pada mata pelajaran sistem komputer kelas $\mathrm{X}$ multimedia di SMK Negeri 3 Singaraja. Model pembelajaran yang diterapkan dalam pengembangan modul elektronik ini adalah model pembelajaran discovery learning.

Jenis penelitian yang digunakan dalam penelitian ini adalah penelitian dan pengembangan (Research and Development) dengan model pengembangan ADDIE. Subjek penelitian ini yaitu siswa kelas $X$ jurusan Multimedia di SMK Negeri 3 Singaraja tahun ajaran 2016/2017. Untuk mengetahui respon guru dan siswa terhadap e-modul sistem komputer diperoleh dengan menggunakan metode angket.

Hasil penelitian yang diperoleh terlihat bahwa (1) Hasil rancangan dan implementasi e-modul berbasis model pembelajaran discovery learning yang telah dikembangkan pada mata pelajaran sistem komputer untuk kelas X Multimedia di SMK Negeri 3 Singaraja dinyatakan berhasil diterapkan berdasarkan beberapa uji yang dilakukan. (2) Hasil analisis data respon guru menunjukkan bahwa, didapatkan rata-rata skor respon sebesar 41, jika dikonversikan ke dalam tabel penggolongan respon maka termasuk pada kategori positif. Sedangkan untuk respon siswa terhadap pengembangan e-modul didapatkan rata-rata skor respon sebesar 64,74, jika dikonversikan ke dalam tabel penggolongan respon siswa termasuk pada kategori positif.
\end{abstract}

Kata kunci: E-Modul, Sistem Komputer, Discovery Learning

\begin{abstract}
This research had purpose: (1) to design and implement an e-module based on discovery learning model for computer system multimedia class major, (2) to know teacher and student responds toward development of e-module based on discovery learning of grade $X$ in SMK Negeri 3 Singaraja.

Learning model which developed for this electronic module is discovery learning. Research and Development method was used in this research, with ADDIE as development model. Subjects of this research were student grade $\mathrm{X}$ of Multimedia major in SMK Negeri 3 Singaraja, year 2016/2017.

Questionnaire with agree and disagree responds was used as a tools to attain teacher and student responds toward e-module computer system. Results of this research showed that: (1) the new design of e-module that was developed successfully implemented based on trials that has done (2) analysis of teacher and student responds data demonstrated positive responds based on conversion of mean responds score, which is 41 and 64.74, respectively.
\end{abstract}

Keywords: E-Module, Computer System, Discovery Learning 


\section{PENDAHULUAN}

SMKN 3 Singaraja merupakan salah satu sekolah kejuruan yang ada di Bali, dimana memiliki banyak jurusan dibidang teknologi, salah satunya yaitu multimedia, Sesungguhnya pembelajaran sudah berjalan dengan baik namun belum optimal, maka dari itu masih diperlukan pembaharuan-pembaharuan seiring dengan kemajuan teknologi.

Berdasarkan hasil observasi dan wawancara yang dilakukan pada tanggal 31 Desember 2015 di SMKN 3 Singaraja terlihat bahwa proses pembelajaran di kelas $X$ multimedia pada mata pelajaran sistem komputer terdapat beberapa masalah, antara lain : 1) Masih menggunakan model pembelajaran konvensional/ceramah yang mana sumber belajar hanya berpusat pada guru. Dilihat dari hasil nilai Ulangan Akhir Semester (UAS) siswa, terlihat dari 31 siswa hanya $38,7 \%$ siswa yang berhasil mencapai Kriteria Ketuntasan Minimal (KKM). Jadi hal ini dapat disimpulkan, jika dengan menggunakan model pembelajaran konvensional/ceramah, kurang efektif pada siswa tesebut. 2) Karakteristik siswa lebih cenderung memiliki sikap yang kurang tanggap/aktif di kelas. 3) Sesuai dengan Permendikbud Nomor 65 Tahun 2013 tentang standar proses pendidikan dasar dan menengah, menjelaskan bahwa diperlukannya pemanfaatan teknologi informasi dan komunikasi untuk meningkatkan efisiensi dan efektivitas dalam proses pembelajaran, Namun guru belum memanfaatkan secara maksimal teknologi di zaman sekarang ini dalam penggunaan bahan ajar, guru hanya menggunakan bahan ajar yang bersumber dari internet yang belum pasti kebenarannya.

Untuk meningkatkan keaktifan siswa di kelas dalam proses pembelajaran, hal itu dapat ditangani dengan menerapkan model pembelajaran, keberhasilan seorang siswa dalam proses pembelajaran tidak saja ditentukan oleh tenaga pengajar yang baik atau kurikulum yang mantap, namun juga ditentukan oleh metode pembelajaran yang digunakan guru (Winda, 2014). Model- model atau metode mengajar tersebut menuntut keaktifan siswa sesuai dengan perkembangan siswa. Keaktifan belajar siswa dapat dilihat dari aktivitas-aktivitas belajar siswa, antara lain: visual activities, oral activities, listening activities, writing activities, drawing activities, motor activities, mental activities, dan emotional activities (Sardirman, 2007).

Untuk memperoleh pencapaian keaktifan yang optimal diperlukan suasana dan lingkungan belajar yang menunjang dan proses belajar yang menarik sehingga dimungkinkan perlu adanya penerapan model pembelajaran yang baik dan tepat yang melibatkan siswa secara aktif. Salah satu model pembelajaran yang membuat peserta didik aktif, dan mandiri dalam proses belajarnya, yang bertanggung jawab dan berinisiatif untuk mengenali kebutuhan belajarnya, menemukan sumber-sumber informasi, untuk dapat menjawab kebutuhannya, membangun serta mempresentasikan pengetahuannya berdasarkan kebutuhan serta sumbersumber yang ditemukan, yaitu model pembelajaran discovery learning.

Kemudian untuk menyediakan bahan ajar yang sesuai dengan perkembangan zaman, maka bisa dibantu dengan pemberian modul ajar, sebuah modul ajar akan bermakna, jika siswa dapat dengan mudah menggunakannya (Wenno, 2010). Adapun modul ajar yang sekarang sesuai dengan perkembangan teknologi adalah berbasis elektronik. Modul ajar elektronik yang saat ini popular adalah Modular Object Oriented Dynamic Learning Environment (Moodle), yaitu modul elektronik yang berbasis web. Moodle adalah sebuah nama untuk sebuah pogram aplikasi yang dapat mengubah sebuah media pembelajaran kedalam bentuk web.

Kelebihan menggunakan Moodle sebagai bahan ajar pada siswa dibandingkan dengan menggunakan bahan ajar lain seperti buku konvensional yaitu lebih interaktif, karena dengan Moodle kita dapat menyisipkan suatu bahan ajar tidak hanya dalam bentuk teks saja, bisa dalam bentuk animasi, audio maupun video yang 
dapat membuat siswa menjadi lebih tertarik dalam mempelajarinya, selain itu pengajar juga dapat mengelola materi pembelajaran, yakni : menyusun silabus, mengupload materi, memberikan tugas kepada peserta didik, menerima pekerjaan mereka, membuat tes/quiz, memberikan nilai, memonitor keaktifan, mengolah nilai, berinteraksi dengan peserta didik dan sesama dan pengajar melalui forum diskusi dan chat (Suartama, 2014).

Berdasarkan penelitian yang sebelumnya dilakukan terkait dengan penelitian pengembangan e-modul, didapatkan beberapa hasil penelitian yang relevan dengan penelitian pengembangan e-modul yaitu, menyatakan bahwa penggunaan e-modul pada siswa jurusan teknik komputer jaringan di SMK Negeri 1 Labang dapat meningkatkan hasil belajar siswa, ini terbukti dari hasil uji t dengan diperolehnya data Thitung lebih besar dari Ttabel (Fausih, 2015).

Berkaitan dengan ini penulis ingin mengembangkan sebuah e-modul yang sedikit berbeda dengan penelitian tersebut yaitu dengan menerapkan salah satu model pembelajaran kurikulum 2013 dalam emodul, yaitu discovery learning. Penelitian yang akan penulis kembangkan ini berjudul "Pengembangan E-Modul Berbasis Model Pembelajaran Discovery Learning Pada Mata Pelajaran "Sistem Komputer" Untuk Siswa Kelas $X$ Multimedia SMKN 3 Singaraja".

\section{METODE}

Penelitian ini merupakan jenis penelitian pengembangan atau research and development (R\&D). Metode pengembangan merupakan cara yang digunakan untuk menemukan, mengembangkan dan menguji suatu produk berdasarkan prosedur yang sistematis, sehingga produk yang dihasilkan memiliki nilai ilmiah yang tinggi dan dapat dipercaya. Produk yang dimaksud berupa modul elektronik TIK dalam bentuk web yang digunakan sebagai media pembelajaran sistem komputer kelas $\mathrm{X}$. Jenis penelitian ini dipilih karena prosedur yang ada di dalamnya sangat tepat untuk melakukan penggembangan sebuah media yang mempunyai tujuan untuk mengembangkan dan memvalidasi produk.

Model pengembangan e-modul ini menggunakan model pengembangan ADDIE, dimana model pengembangan ini terdiri dari 5 tahapan yaitu Analysis (analisis), Design (desain), Development (pengembangan), Implementation (implementasi) dan Evaluation (evaluasi). Model ini dipilih karena model pengembangan instruksional ini bisa digunakan untuk membantu menyelesaikan permasalahan pembelajaran yang komplek dan juga mengembangkan produk-produk pendidikan dan pembelajaran. Model ADDIE merupakan model pembelajaran yang bersifat umum dan sesuai digunakan untuk penelitian pengembangan. Dalam penelitian ini digunakan instrumen berupa angket untuk mengumpulkan data yang dibutuhkan terkait informasi tentang sumber belajar, karakteristik siswa, uji kevalidan emodul, serta uji respon guru dan siswa terhadap e-modul yang dikembangkan. Teknik pengumpulan data dapat dilihat pada Tabel 1.

Tabel 1 Teknik Pengumpulan Data

\begin{tabular}{clcl}
\hline No. & \multicolumn{1}{c}{ Jenis Data } & Metode & \multicolumn{1}{c}{ Sumber Data } \\
\hline 1 & $\begin{array}{l}\text { Informasi tentang } \\
\text { sumber belajar }\end{array}$ & Angket & $\begin{array}{l}\text { Guru Mata Pelajaran Sistem Komputer dan } \\
\text { peserta didik kelas X Multimedia di SMKN 3 } \\
\text { Singaraja }\end{array}$ \\
2 & Karakteristik siswa & Angket & $\begin{array}{l}\text { Peserta didik kelas X Multimedia di SMKN 3 } \\
\text { Singaraja }\end{array}$ \\
3 & Kevalidan E-modul & Angket & $\begin{array}{l}\text { Ahli Isi Pembelajaran, Ahli Desain } \\
\text { Pembelajaran, dan Ahli Media Pembelajaran } \\
\text { Guru Mata Pelajaran Sistem Komputer dan } \\
\text { peserta didik kelas X Multimedia di SMKN 3 } \\
\text { Singaraja }\end{array}$ \\
\hline
\end{tabular}


Pada kegiatan observasi guna mendapat informasi sumber belajar dan karakteristik pembelajar, digunakan jenis angket terbuka. Melalui metode angket ini peneliti mengetahui masalah yang terjadi ketika pembelajaran berlangsung terkait sumber belajar, materi, media, dan ketertarikan siswa dalam pembelajaran sistem komputer. Uraian singkat tentang teknis analisis data yang digunakan dalam penelitian ini adalah sebagai berikut.

1. Validasi data e-modul

Penilaian persentase hasil yang diperoleh menggunakan rumus sebagai berikut (Addalena, 2015).

Persentase $=\frac{\text { Skor Perolehan }}{\text { Skor Maksimal }} \times 100 \%$

Untuk melihat tingkat pencapaian pengembangan e-modul berdasarkan perhitungan persentase maka ditetapkan kriteria sesuai tabel tingkat pencapaian seperti terlihat pada Tabel 2 (Agung, 2011).

2. Analisis data respon guru dan siswa

Dalam melakukan perhitungan analisis data respon maka didasarkan pada rata kelas $(\bar{x})$ dari respon peserta didik, Mi, dan SDi. Rata-rata kelas dari skor respon peserta didik dihitung dengan rumus (Nurkancana, 1995).

$\bar{x}=\frac{\sum x}{N}$

Keterangan:

$\bar{x}=$ Rata - rata kelas untuk skor respon siswa

$\sum x=$ Jumlah skor respon siswa

$\mathrm{N}$ = Banyaknya siswa

Sedangkan untuk mencari mean ideal (Mi) dan standar deviasi ideal (SDi) digunakan rumus sebagai berikut:

$\mathrm{Mi}=\frac{1}{2}($ skor maksimal + skor terendah $)$

$\mathrm{SDi}=\frac{1}{2}($ skor tertinggi + skor terendah $)$

Rata-rata kelas $(\bar{x})$ dari skor respon kemudian dikategorikan dengan menggunakan pedoman pada Tabel 3 .

\section{HASIL DAN PEMBAHASAN}

Pengembangan e-modul sistem komputer bertujuan untuk membantu meningkatkan kualitas sumber belajar yang terdapat disekolah, mempermudah siswa dalam belajar, meningkatkan kemandirian siswa, menambah media guru dalam melakukan kegiatan pembelajaran di kelas dan meningkatkan pengetahuan serta pemahaman siswa terhadap mata pelajaran sistem komputer. Pada saat melakukan obsevasi awal disekolah SMKN 3 Singaraja didapat bahwa siswa dalam melakukan proses pembelajaran di kelas hanya mendengarkan penjelasan dari guru kemudian mencatatnya sebagai bahan pelajaran, siswa belum memiliki modul ajar atau buku pelajaran untuk mata pelajaran sistem komputer yang sesuai tuntutan kurikulum 2013 yang berlaku di sekolah tersebut, selain itu guru juga belum memanfaatkan fasilitas yang disediakan disekolah sebagai media untuk melakukan proses belajar mengajar di kelas. Hal ini tentu berdampak bagi siswa yang menyebabkan mereka menjadi kurang aktif, tidak mandiri, dan mengalami kesusahan dalam mempelajarai dan memahami materi sistem komputer, oleh karena itu pengembangan e-modul pada mata pelajaran Sistem Komputer di kelas $X$ Multimedia SMKN 3 Singaraja sangat diperlukan guna untuk meningkatkan kualitas pembelajaran yang dapat meningkatkan pemahaman siswa.

Pengembangan e-modul sistem komputer ini menggunakan model pembelajaran discovery learning yang bertujuan untuk membuat peserta didik aktif, dan mandiri dalam proses belajarnya, bertanggung jawab dan berinisiatif untuk mengenali kebutuhan belajarnya, menemukan sumber-sumber informasi, untuk dapat menjawab kebutuhannya, membangun serta mempresentasikan pengetahuannya berdasarkan kebutuhan serta sumber-sumber yang ditemukan.

Sesuai dengan hasil dari penelitian berikut ini akan diuraikan pembahasan dari hasil penelitian yang sudah diperoleh. Pembahasan difokuskan pada penyajian dan analisis data serta revisi yang 
Tabel 2 Konversi Tingkat Pencapaian

\begin{tabular}{lll}
\hline $\begin{array}{l}\text { Tingkat } \\
\text { Pencapaian }\end{array}$ & Kualifikasi & Keterangan \\
\hline $90 \%-100 \%$ & Sangat baik & $\begin{array}{l}\text { Tidak perlu } \\
\text { direvisi } \\
\text { Tidak perlu } \\
\text { direvisi }\end{array}$ \\
$75 \%-89 \%$ & Baik & Direvisi \\
$65 \%-74 \%$ & Cukup & Direvisi \\
$55 \%-64 \%$ & Kurang & Direvisi \\
$0 \%-54 \%$ & Sangat & \\
& kurang & \\
\hline
\end{tabular}

dilakukan terhadap produk pengembangan. Pengembangan penelitian ini menggunakan model ADDIE, dimana tahapan pertama yang dilakukan adalah analisis (analyze) meliputi kegiatan analisis mata pelajaran yang terdiri dari : a) Analisis Karakteristik Siswa, b) Analisis Sumber Belajar c) Analisis Tujuan dan Karakteristik Isi Bidang Studi, d) Menetapkan Indikator dan Isi Pembelajaran, e) Menetapkan Strategi Pengorganisasian Isi Pembelajaran, f) Menetapkan Strategi Penyampaian Isi Pembelajaran, dan g) Menetapkan Strategi Pengelolaan Pembelajaran. Tahap kedua adalah perancangan (design) meliputi penyusunan draft modul dan perancangan e-modul.

Kemudian tahap ketiga adalah pengembangan (development) yang meliputi kegiatan pengembangan modul, pengembangan e-modul, dan integrasi fitur Moodle pada e-modul. Kegiatan penyusunan modul meliputi pengumpulan bahan/materi pelajaran, pengetikan bahan ajar, pembuatan gambar-gambar pada materi pelajaran dan penyusunan materi yang sesuai dengan silabus yang berlaku. Kegiatan pengembangan e-modul meliputi pengembangan rancangan antarmuka pada aplikasi Moodle berdasarkan rancangan struktur menu (sitemap), dan mengatur hak akses pengguna e-modul. Sedangkan kegiatan pengembangan integrasi fitur Moodle pada e-modul meliputi penerapan isi dari modul ke dalam Moodle hingga menjadi produk akhir berupa e-modul. Pengembangan pada fitur Moodle disesuaikan dengan kerangka modul yang digunakan dan berisikan implementasi
Tabel 3 Kriteria Penggolongan Respon Dengan Skala 5

\begin{tabular}{cll}
\hline No & \multicolumn{1}{c}{ Interval } & Kategori \\
\hline 1 & $\mathrm{Mi}+1,5 \mathrm{SDi} \leq \bar{x}$ & Sangat \\
& & Positif \\
2 & $\mathrm{Mi}+0,5 \mathrm{SDi} \leq \bar{x}<$ & Positif \\
& $\mathrm{Mi}+1,5 \mathrm{SDi}$ & \\
3 & $\mathrm{Mi}-0,5 \mathrm{SDi} \leq \bar{x}<$ & Kurang \\
& $\mathrm{Mi}+0,5 \mathrm{SDi}$ & Positif \\
4 & $\mathrm{Mi}-1,5 \mathrm{SDi} \leq \bar{x}<$ & Negatif \\
& $\mathrm{Mi}-1,5 \mathrm{SDi}$ & \\
5 & $\bar{x}<\mathrm{Mi}-1,5 \mathrm{SDi}$ & Sangat \\
& & Negatif \\
\hline
\end{tabular}

tahapan model discovery learning pada emodul.

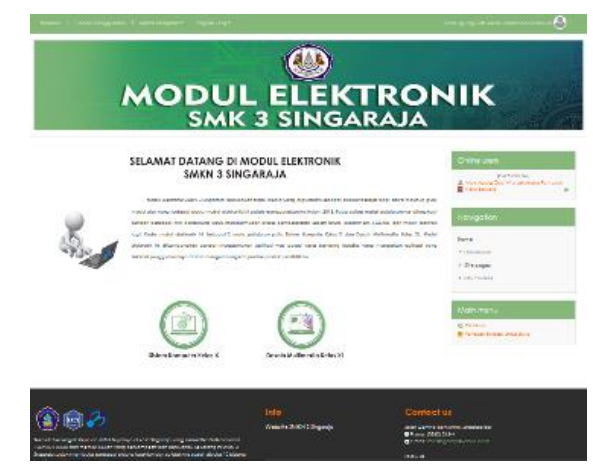

Gambar 1. Halaman Utama Pengguna

Tahap keempat adalah implementasi (implementation) kegiatan yang dilakukan pada tahap ini yaitu dengan menguji coba e-modul sesuai dengan peran dan fungsinya dalam proses pembelajaran untuk mengetahui sampai sejauh mana manfaat produk yang sudah dikembangkan. Tahapan uji coba dimulai dari review para ahli, kemudian dilanjutkan dengan uji coba perorangan, kelompok kecil, dan uji lapangan. Uji ahli yang pertama dilakukan adalah uji ahli isi pembelajaran. Setelah selesai melakukan uji ahli isi, kemudian dilanjutkan dengan uji ahli desain dan ahli media pembelajaran.

Hasil penilaian ahli isi berdasarkan angket menunjukkan bahwa tingkat pencapaian dari e-modul adalah "SESUAl" dan layak untuk dilanjutkan. Hal tersebut menandakan bahwa materi pelajaran yang sudah diterapkan di dalam e-modul sudah layak dan mampu digunakan dalam pembelajaran sistem komputer. Materi 
pelajaran pada e-modul yang menggunakan materi dari beberapa sumber buku sebagai referensi pembelajaran dinyatakan valid dan sudah sesuai dengan kompetensi dasar dan tujuan pembelajaran yang terdapat pada silabus sistem komputer. Dalam uji ahli isi, ahli hanya memberikan komentar dan masukan yang sifatnya membangun, sehingga dalam uji ahli isi ini tidak terdapat revisi yang diberikan oleh ahli.

$\begin{array}{ccc}\text { Hasil penilaian ahli desain } \\ \text { pembelajaran } & \text { terhadap } & \text { produk }\end{array}$ pengembangan e-modul yang terdiri dari kelayakan isi, penyajian, tahap pembelajaran model discovery learning, dan model pembelajaran sudah dinyatakan "SESUAl" dan layak untuk dilanjutkan. Hal tersebut menandakan bahwa penerapan model pembelajaran discovery learning dalam e-modul sudah layak untuk digunakan dalam pembelajaran sistem komputer. Dengan menerapkan langkahlangkah model discovery learning dalam pembelajaran mampu membuat siswa menjadi lebih aktif untuk menggali pengetahuannya dan membuatnya menjadi lebih mandiri dalam proses belajar mengajar. Adapun masukan dan saran dari ahli desain seperti penambahan waktu pengerjaan pada soal kuis untuk siswa, dan membuat manual book untuk admin, sudah dilakukan revisi oleh penulis sesuai dengan saran dari ahli desain.

Hasil penilaian ahli media pembelajaran yang terdiri dari penggunaan bahasa dan keterbacaan, grafis, desain tampilan e-modul, efektivitas, dan media yang dikembangkan dalam e-modul sistem komputer telah dinyatakan "SESUAl" oleh Bapak I Gede Mahendra Darmawiguna, S.Kom., M.Sc dan layak untuk dilanjutkan, namun dari Bapak I Made Putrama, S.T, M.Tech masih terdapat beberapa penilaian yang masih belum sesuai yaitu pemilihan jenis dan ukuran huruf, serta ketepatan pemilihan warna tampilan e-modul, penulis sudah melakukan revisi dari segi jenis dan ukuran huruf dengan menggunakan jenis huruf century gothic untuk kontennya sedangkan untuk materi yang terdapat pada e-modul penulis menggunakan huruf Times New Roman dan untuk ukurannya sudah disesuaikan agar bisa dibaca pengguna. Revisi yang dilakukan pada pemilihan warna tampilan e-modul sudah disesuaikan dengan nuansa tema yaitu hijau sesuai permintaan dari ahli media.

Media pembelajaran dalam e-modul disajikan dalam bentuk teks, gambar, games, dan animasi, dengan tepat dan jelas, sehingga siswa dengan mudah dapat belajar dan memahami materi sistem komputer. Hasil penilaian ahli media menandakan bahwa produk e-modul yang sudah dikembangkan layak untuk digunakan dalam pembelajaran sistem komputer. Adapun masukan dan saran dari ahli media, yang diberikan adalah seperti : Penggunaan huruf sebaiknya yang lebih jelas untuk konten dan konsisten, warna tema sebaiknya yang selaras dengan nuansa tema. Kedua saran atau masukan dari ahli tersebut sudah dilakukan revisi oleh penulis guna untuk meningkatkan kualitas e-modul yang akan dihasilkan.

Kegiatan berikutnya yaitu melakukan implementasi yang meliputi uji perorangan, uji kelompok kecil, uji lapangan, uji respon guru, dan uji respon siswa. Subjek uji perorangan adalah tiga orang siswa kelas $X$ Multimedia di SMKN 3 Singaraja. Dari hasil angket uji coba yang sudah diisi oleh masing-masing siswa, terdapat satu orang siswa memberikan tanggapan sangat baik $(33,33 \%)$, dua orang siswa yang memberikan tanggapan baik $(66,67 \%)$, dan tidak ada siswa yang memberikan tanggapan cukup, kurang, maupun sangat kurang. Rata-rata penilaian siswa adalah $89,00 \%$. Jika dikonversikan ke dalam tabel konversi termasuk dalam kategori baik dan tidak perlu revisi. Pemilihan ketiga subjek yang menjadi responden ini didasarkan pada prestasi mereka yaitu 1 prestasi tinggi, 1 dengan prestasi sedang, dan 1 dengan prestasi rendah, namun dari ketiga responden ini mereka sudah mampu mengoperasikan e-modul dengan baik setelah penulis menjelaskan mengenai $\mathrm{e}$ modul yang sudah dikembangkan, oleh karena itu tidak ada kendala yang didapat saat melakukan uji perorangan ini, semua responden sangat antusias ketika mereka melakukan uji coba untuk e-modul yang sudah dikembangkan ini. Hasil rekapitulasi penilaian pada uji coba perorangan dapat dilihat pada Tabel 4. 
Tabel 4 Rekapitulasi Penilaian Pada Uji Coba Perorangan

\begin{tabular}{lcc}
\hline $\begin{array}{l}\text { Konversi tingkat } \\
\text { pencapaian }\end{array}$ & Persentase (\%) & $\begin{array}{l}\text { Jumlah Responden } \\
\text { (orang) }\end{array}$ \\
\hline Sangat Baik & $33,33 \%$ & 1 \\
Baik & $66,67 \%$ & 2 \\
Cukup & $0 \%$ & 0 \\
Kurang & $0 \%$ & 0 \\
Sangat Kurang & $0 \%$ & 0 \\
\hline
\end{tabular}

Setelah kegiatan uji perorangan selesai, kemudian dilanjutkan dengan uji kelompok kecil. Uji kelompok kecil dilakukan oleh dua belas orang siswa kelas $X$ Multimedia di SMKN 3 Singaraja. Dari hasil angket uji coba kelompok kecil yang sudah diisi tiap siswa, terdapat delapan orang siswa yang memberikan tanggapan sangat baik $(66,67 \%)$, empat orang siswa memberikan tanggapan baik (33,33\%), dan tidak ada siswa yang memberikan tanggapan cukup, kurang, maupun sangat kurang. Rata-rata penilaian dua belas orang siswa adalah 90,33\%. Jika dikonversikan ke dalam tabel konversi termasuk dalam kategori sangat baik dan tidak perlu revisi. Adapun pemaparan beberapa masukan yang telah dirangkum oleh peneliti sebagai dasar untuk melakukan revisi adalah emodul dikatakan telah baik dan sangat bermanfaat, karena dengan adanya emodul ini membuat siswa mudah memahami materi pelajaran, belajar dengan menggunakan e-modul lebih mudah dimengerti, sangat membantu dalam belajar kelompok, dengan adanya emodul menambah semangat dalam belajar, e-modul dilengkapi dengan gambar sehingga belajar menjadi lebih menarik dan tidak cepat bosan. Hasil rekapitulasi penilaian pada uji coba kelompok kecil dapat dilihat pada Tabel 5 .

Setelah kegiatan uji coba kelompok kecil selesai dilakukan, kemudian dilanjutkan dengan uji lapangan yang dilakukan oleh dua puluh tiga orang siswa kelas X Multimedia di SMKN 3 Singaraja. Dari hasil angket uji coba diperoleh sepuluh orang siswa memberikan tanggapan sangat baik $(43,48 \%)$, tiga belas orang siswa memberikan tanggapan baik $(56,52 \%)$, dan tidak ada siswa yang memberikan tanggapan cukup, kurang, maupun sangat kurang. Rata-rata penilaian keseluruhan responden uji lapangan adalah $85,74 \%$. Jika dikonversikan ke dalam tabel konversi tingkat pencapaian termasuk dalam kategori baik dan tidak perlu revisi. Berdasarkan temuan di lapangan pada saat dilakukannya uji lapangan, siswa terlihat sangat antusias mengikuti proses pembelajaran dengan menggunakan emodul, mereka terlihat sangat asik dalam mengoperasikan e-modul bersama dengan siswa-siswa lainnya, Selain itu penggunaan e-modul dalam proses kegiatan belajar mengajar di kelas dapat membantu siswa menjadi lebih tanggap, aktif, dan meningkatkan interaksi antar guru dan siswa. Dengan menggunakan model discovery learning sebagai tahapan dalam setiap kegiatan belajar mengajar, terbukti mampu menumbuhkembangkan keaktifan siswa dan kemandirian siswa dalam kegiatan belajar mengajar di kelas. Hasil rekapitulasi penilaian pada uji coba lapangan dapat dilihat pada Tabel 6.

Setelah hasil uji lapangan didapatkan, tahapan berikutnya dilakukan pengambilan respon guru terhadap pengembangan e-modul pada mata pelajaran sistem komputer. Uji respon guru dilakukan oleh satu orang responden yaitu lbu Putu Intan Paramita, S.Pd dan memperoleh rata-rata sebesar 41 , jika dikonversikan ke dalam tabel kriteria penggolongan respon maka hasilnya termasuk dalam kategori positif. Proses uji selanjutnya dilakukan dengan pengambilan respon siswa. Subjek uji coba respon siswa adalah terdiri dari 23 orang siswa kelas $X$ Multimedia yang telah melakukan kegiatan belajar mengajar di kelas dengan menggunakan e-modul. Hasil angket respon siswa terhadap pengembangan emodul sistem komputer memperoleh ratarata sebesar 64,74, jika dikonversikan ke dalam tabel kriteria penggolongan respon 
Tabel 5 Rekapitulasi Penilaian Pada Uji Coba Kelompok Kecil

\begin{tabular}{lcc}
\hline $\begin{array}{c}\text { Konversi tingkat } \\
\text { pencapaian }\end{array}$ & $\begin{array}{c}\text { Persentase } \\
(\%)\end{array}$ & $\begin{array}{c}\text { Jumlah Responden } \\
\text { (orang) }\end{array}$ \\
\hline Sangat Baik & $33,33 \%$ & 8 \\
Baik & $66,67 \%$ & 4 \\
Cukup & $0 \%$ & 0 \\
Kurang & $0 \%$ & 0 \\
Sangat Kurang & $0 \%$ & 0 \\
\hline
\end{tabular}

Tabel 6 Rekapitulasi Penilaian Pada Uji Coba Lapangan

\begin{tabular}{lcc}
\hline $\begin{array}{c}\text { Konversi tingkat } \\
\text { pencapaian }\end{array}$ & Persentase (\%) & $\begin{array}{c}\text { Jumlah Responden } \\
\text { (orang) }\end{array}$ \\
\hline Sangat Baik & 43,48 & 10 \\
Baik & 56,52 & 13 \\
Cukup & $0 \%$ & 0 \\
Kurang & $0 \%$ & 0 \\
Sangat Kurang & $0 \%$ & 0 \\
\hline
\end{tabular}

maka hasilnya termasuk dalam kategori positif. Berdasarkan hasil respon guru dan siswa dapat dikategorikan bahwa e-modul sistem komputer yang berbasis model pembelajaran discovery learning membantu siswa dalam memahami mata pelajaran sistem komputer dan menambah sumber belajar siswa maupun guru dalam memahami sistem komputer khususnya untuk kelas $\mathrm{X}$ program keahlian Teknologi Informasi dan Komunikasi.

Hasil penelitian e-modul berbasis model pembelajaran discovery learning pada mata pelajaran sistem komputer ini sejalan dengan penelitian Fausih dan Danang (2015) tentang Pengembangan Emodul Mata Pelajaran Produktif Pokok Bahasan "Instalasi Jaringan LAN" Untuk Siswa Kelas XI Jurusan Teknik Komputer Jaringan di SMK Negeri 1 Labang Bangkalan Madura yaitu sama-sama memperoleh penilaian layak pada uji coba perorangan, kelompok kecil, dan lapangan untuk diimplementasikan sebagai media pembelajaran. Penelitian terkait lainya yang dilakukan oleh Rizky Prima (2013), dalam implementasi e-modulnya, kuis yang terdapat pada kegiatan belajar 1 sampai dengan 3 dilengkapi dengan password sehingga siswa tidak bisa mengaksesnya sebelum guru memberikan password kepada siswa, sedangkan pada pengembangan e-modul yang penulis kembangkan hampir sama dengan pengembangan yang dilakukan Rizky Prima (2013) yaitu dengan menggunakan restrict acces dimana kuis tersebut tidak bisa diakses sebelum siswa menyelesaikan setiap tahapan pembelajaran.

Berdasarkan pembahasan di atas, penilaian-penilaian yang dilakukan oleh ahli isi, ahli desain pembelajaran, ahli media, uji coba perorangan, uji coba kelompok kecil, uji lapangan, maupun hasil respon guru dan siswa termasuk dalam kategori baik dan mendapat respon positif. Berdasarkan penilaian tersebut, secara garis besar pengembangan e-modul berbasis model pembelajaran discovery learning pada mata pelajaran sistem komputer untuk kelas $\mathrm{X}$ telah menunjukkan adanya keberhasilan dan layak digunakan sebagai sumber belajar untuk siswa kelas X Multimedia di SMKN 3 Singaraja. Hal ini didukung pula dengan beberapa pernyataan siswa yaitu emodul ini membuat siswa mudah memahami materi pelajaran, belajar dengan menggunakan e-modul lebih 


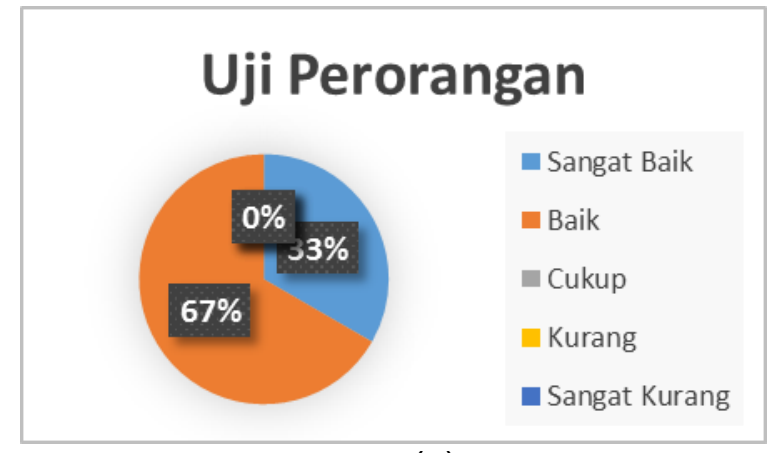

(a)

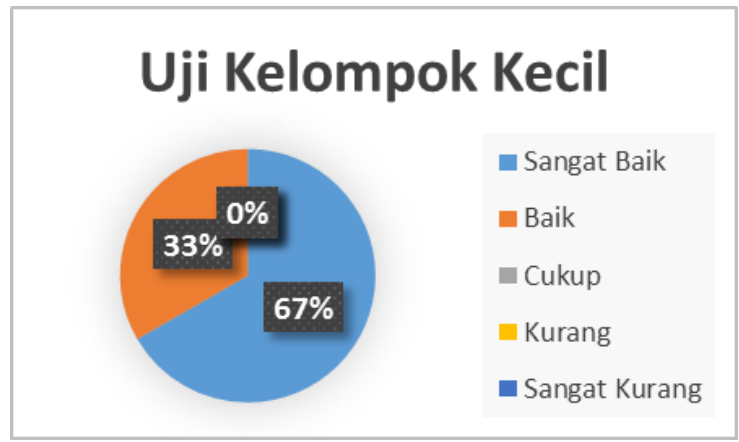

(b)

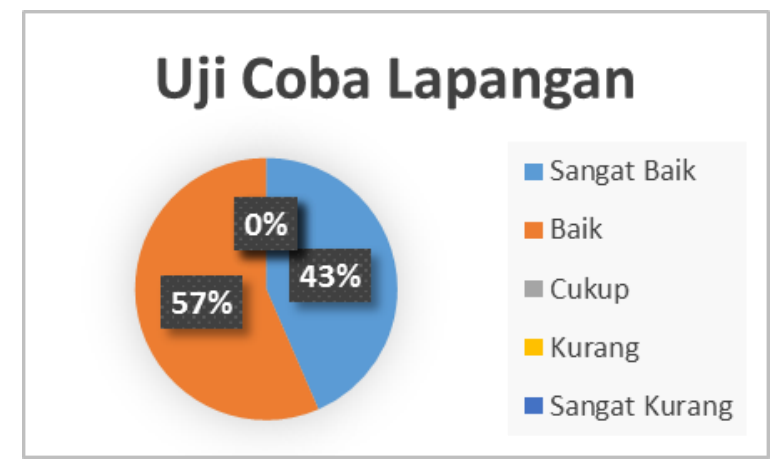

(c)

Gambar 2. Grafik Hasil Rekapitulasi Uji Pengguna, (a) Uji Perorangan; (b) Uji Kelompok Kecil; (c) Uji Lapangan

mudah dimengerti, sangat membantu dalam belajar kelompok, dengan adanya emodul menambah semangat dalam belajar, e-modul dilengkapi dengan gambar sehingga belajar menjadi lebih menarik dan tidak cepat bosan. Dengan diterapkannya e-modul sistem komputer ini diharapkan dapat membantu guru selama proses pembelajaran dan masalah selama proses pembelajaran terkait sumber belajar mampu teratasi, serta mampu membuat peserta didik aktif, dan mandiri dalam proses belajarnya, bertanggung jawab dan berinisiatif untuk mengenali kebutuhan belajarnya, menemukan sumber-sumber informasi untuk dapat menjawab kebutuhannya, dan membangun serta mempresentasikan pengetahuannya berdasarkan kebutuhan serta sumbersumber yang ditemukan.

\section{SIMPULAN DAN SARAN}

Berdasarkan hasil penelitian dan pembahasan, maka penulis dapat menarik kesimpulan sebagai berikut.
Pengembangan e-modul sistem komputer berbasis model pembelajaran discovery learning ini menggunakan model pengembangan ADDIE, dimana tahapan pertama yang dilakukan adalah analisis (analyze) meliputi kegiatan analisis mata pelajaran yang terdiri dari : a) Analisis Karakteristik Siswa, b) Analisis Sumber Belajar c) Analisis Tujuan dan Karakteristik Isi Bidang Studi, d) Menetapkan Indikator dan Isi Pembelajaran, e) Menetapkan Strategi Pengorganisasian Isi Pembelajaran, f) Menetapkan Strategi Penyampaian Isi Pembelajaran, dan g) Menetapkan Strategi Pengelolaan Pembelajaran. Tahap kedua adalah perancangan (design) meliputi penyusunan draft modul dan perancangan e-modul.

Tahap ketiga adalah pengembangan (development) yang meliputi kegiatan pengembangan modul, pengembangan emodul, dan integrasi fitur Moodle pada emodul. Tahap keempat adalah implementasi (implementation) kegiatan yang dilakukan pada tahap ini yaitu dengan menguji coba e-modul sesuai dengan peran 
dan fungsinya dalam proses pembelajaran untuk mengetahui sampai sejauh mana manfaat produk yang sudah dikembangkan. (2) Respon guru terhadap pengembangan e-modul pada mata pelajaran sistem komputer berbasis model pembelajaran discovery learning memperoleh rata-rata sebesar 41, yang jika dikonversikan ke dalam tabel kriteria penggolongan respon maka hasilnya termasuk dalam kategori positif. Sedangkan dari segi respon siswa terhadap pengembangan e-modul sistem komputer berbasis model pembelajaran discovery learning memperoleh rata-rata sebesar 64,74, yang jika dikonversikan ke dalam tabel kriteria penggolongan respon maka hasilnya termasuk dalam kategori positif.

Berdasarkan pengamatan penulis, terdapat beberapa hal yang dapat dijadikan bahan pertimbangan untuk ditindak lanjuti. (1) Pengembangan e-modul pada mata pelajaran sistem komputer ini hanya sampai pada kegiatan belajar pada semester ganjil, jadi diharapkan untuk peneliti selanjutnya agar dapat mengembangkannya menjadi 1 tahun pelajaran. (2) Produk e-modul ini hanya menghasilkan produk berupa aplikasi e-modul sistem komputer, oleh karena itu maka perlu diadakan pengkajian lebih lanjut mengenai efektivitas penggunaan emodul berkaitan dengan hasil belajar atau prestasi belajar siswa. (3) Bagi pembaca dapat mengembangkan penelitian e-modul ini menjadi penelitian eksperimen. (4) Pengujian produk e-modul pada mata pelajaran sistem komputer kelas $X$ Multimedia di SMK Negeri 3 Singaraja hanya terdiri dari uji ahli isi pembelajaran, ahli desain pembelajaran, ahli media pembelajaran, dan uji coba terbatas, untuk selanjutnya perlu dilakukan pengujian untuk menilai usability dan user experience dari sistem e-modul sistem komputer. (5) Bagi pengembang e-modul selanjutnya agar dapat mengatur e-modul lebih user friendly atau mudah digunakan bagi pengguna yang masih belum terbiasa dengan pembelajaran berbasis komputer.

\section{DAFTAR PUSTAKA}

Addalena, K. S. (2015). Pengembangan Modul Ajar Pemrograman WEB
Dengan Konsep Scientifik

Berorientasi Project Based Learning Di SMK Negeri 2 Seririt. Skripsi (tidak diterbitkan).

Agung, A. A. (2011). Metode Penelitian Pendidikan : Suatu Pengantar. Singaraja: Fakultas IImu Pendidikan, Universitas Pendidikan Ganesha.

Fausih, M. (2015). Pengembangan Media E-Modul Mata Pelajaran Produktif Pokok Bahasan "Instalasi Jaringan LAN (Local Area Network)" untuk Siswa Kelas XI Jurusan Teknik Komputer Jaringan Di SMK Negeri 1 Labang Bangkalan Madura. 1-9.

Nurkancana, W., \& Sunartana. (1992). Evaluasi hasil belajar. Surabaya: Usaha Nasional.

Sardirman. (2007). Interaksi dan Motivasi Belajar Mengajar. Jakarta: P.T. Raja Grafindo Persada.

Suartama, I. K. (2014). E-Learning Berbasis Moodle. GRAHA ILMU.

Wijayanto, M. S. (2014). Pengembangan EModul Berbasis Flip Book Maker dengan Model Project Based Learning untuk Mengembangkan Kemampuan Pemecahan Masalah Matematika. Prosiding Mathematics and Sciences Forum, 1-4.

Winda, M. (2014). Peningkatan Keaktifan Siswa Melalui Penerapan Metode Discovery dalam Pembelajaran PKn di Kelas X2 SMA Negeri 2 Lengayang Pesisir Selatan. TINGKAP, 43-57.

Wenno, I. H. (2010). Pengembangan Model Modul IPA Berbasis Problem Solving Method Berdasarkan Karakteristik Siswa Dalam Pembelajaran Di SMP/MTs. Cakrawala Pendidikan, 313. 